\title{
Analysis of Patient Safety Culture Among Nurses in Inpatient and Outpatient Care Unit Jambi Teaching Hospital
}

\author{
Muthia Mutmainnah ${ }^{* 1}$, Kamariyah ${ }^{1,}$ Luri Mekeama $^{1,}$ Nila Budi Setia ${ }^{2,}$ Muhammad \\ Syir $^{2}$
}

\author{
${ }^{1}$ Lecturer in the Department of Nursing, Faculty of Medicine and Health Sciences, Jambi University \\ ${ }^{2}$ Raden Mattaher Teaching Hospital, Jambi \\ *Email: muthia_mutmainnah@unja.ac.id
}

\begin{abstract}
Patient safety has become a global concern since the publication of the Institute of Medicine report in 1990. Nurses are health workers who play a very important role in patient safety. The patient is on the nurse's responsibility 24 hours a day. Nurses fulfill all the basic needs of the patient every day, especially in patient safety. The purpose of this study was to determine patient safety culture at Jambi Teaching Hospital. This cross-sectional study was carried out on sample of 128 nurses in public hospital in Jambi. total sampling was used in this study. Data were collected using patient safety culture questionnaire (HSOPSC) by Radloff which consists of 12 factors and 42 question items. SPSS were used to perform statistical analysis. Most of respondents (69,5\%) stated cooperation within units in high categorized, supervision $(80.5 \%)$ was in moderate category, organizational learning $(69.5 \%)$ was in moderate category, management support $(68 \%)$ was in moderate category, perceptions of patient safety $(85.9 \%)$ in moderate category, cooperation between units $(88.3 \%)$ in moderate category, staffing $(89.8 \%)$ in moderate category, hands-off \& transition $(60.9 \%)$ in moderate category, Non punitive response $(80.5 \%)$ in moderate category, feedback $(64.8 \%)$ in moderate category, communication open $(88.3 \%)$ in moderate category, frequency of incident reporting $(75 \%)$ in moderate category. The results of this study have shown overall patient safety culture in the Outpatient and Inpatient care unit of Jambi Teaching Hospital. Hospitals need to create good patient safety culture to increase nurse job satisfaction which affects the performance of nurses and the rate of insiden report.
\end{abstract}

Keywords: Patient Safety Culture.

\section{BACKGROUND}

Complex health services that involve a variety of health workers have created a risk of negligence, disability and even unwanted death. These unwanted events can occur from events that do not cause side effects to cause death. Patient safety is often overlooked because of considerations in the cost of care. Responding to payer constraints, many hospitals have begun reducing costs by shortening the length of stay in the hospital, cutting nursing staff, and increasing workloads. [1]

The world health organization has estimated that tens of millions of patients are victims of injuries and death from negligence, and unprotected medical care around the world. Medical error in US annually result in 44000 to 98000 death in hospital. Based on the available evidence, it is estimated that in developed countries, 1 out of patients will be injured during services.

Nurses are health workers who play a very important role in patient safety. The patient is on the nurse's responsibility 24 hours a day. The nurse plays an important role in all aspects of patient care, such as provide direct care, giving education, and coordinate with all health workers related to patient treatment and care. Nurses are in control in meeting all the basic needs of patients on a daily basis. This study aims to determine the application of patient safety culture related to patient safety incidents in the Inpatient and outpatient Care unit. 


\section{METHOD}

The aim of this study is to analyse patient safety culture in the Inpatient and Outpatient Care unit, Jambi teaching Hospital, this cross-sectional study was conducted in selected public hospital in Jambi. The investigation was carried out from agustus 2020 to Desember 2021 on sample of 128 nurses in public hospital in Jambi. total sampling was used in this study. Data were collected using patient safety culture questionnaire (HSOPSC) by Radloff which consists of 12 factors and 42 question items. SPSS were used to perform statistical analysis. In this study, full-time employment, the physical and mental desire and ability to participate, and having more than 6 months of work in the hospital were defined as inclusion criteria.

\section{RESULTS}

Based on table 1, 95.3\% of 128 respondent were female, $46.1 \%$ or 59 respondents aged $26-35$ years, $62,5 \%$ or 80 respondents was graduated in diploma. $94.5 \%$ of all respondents who work in inpatient care units were married, $59.4 \%$ of respondent are civil servants. $50,8 \%$ of all respondent have been work for more than 10 years.

Table 1. Characteristics of Respondents

\begin{tabular}{|c|c|c|c|}
\hline$\frac{\text { No. }}{1 .}$ & Variable & $\mathrm{n}$ & $\%$ \\
\hline \multirow[t]{34}{*}{1.} & Characteristics Respondent & & \\
\hline & $\begin{array}{l}\text { Age } \\
26-35 \text { years }\end{array}$ & 59 & 46,1 \\
\hline & $36-45$ years & 44 & 34,4 \\
\hline & $46-55$ years & 23 & 18,0 \\
\hline & $56-60$ years & 2 & 1,6 \\
\hline & Total & 128 & 100 \\
\hline & b. Gender & & \\
\hline & Male & 6 & 4,7 \\
\hline & Female & 122 & 95,3 \\
\hline & Total & 128 & 100 \\
\hline & c. Last Education & & \\
\hline & Diploma 3 in Nursing & 80 & 62,5 \\
\hline & Diploma 4 Nursing & 7 & 5,5 \\
\hline & Bachelor in Nursing & 39 & 30,5 \\
\hline & Master in Nursing & 2 & 1,6 \\
\hline & Total & 128 & 100 \\
\hline & d. Unit Kerja & & \\
\hline & Inpatient Care unit & 121 & 94,5 \\
\hline & Outpatient Care unit & 7 & 5,5 \\
\hline & Total & 128 & 100 \\
\hline & e. Marital Status & & \\
\hline & Married & 7 & 5,5 \\
\hline & Single & 121 & 94,5 \\
\hline & Total & 128 & 100 \\
\hline & f. Employment status & & \\
\hline & PNS & 76 & 59,4 \\
\hline & Contract worker & 52 & 40,6 \\
\hline & Total & 128 & 100 \\
\hline & g. Length of work & & \\
\hline & $1-3$ year & 8 & 6,3 \\
\hline & 3-5 year & 12 & 9,4 \\
\hline & $5-10$ year & 43 & 33,6 \\
\hline & $>10$ year & 65 & 50,8 \\
\hline & Total & 128 & 100 \\
\hline
\end{tabular}


Table 2. Dimensions of Patient Safety Culture

\begin{tabular}{|c|c|c|c|c|c|}
\hline \multirow{2}{*}{ Patient safety culture } & \multicolumn{3}{|c|}{ Kategori } & \multirow{2}{*}{$\mathrm{n}$} & \multirow{2}{*}{$\%$} \\
\hline & Rendah & Sedang & Tinggi & & \\
\hline \multirow{2}{*}{ Cooperation in unit } & 1 & 38 & 89 & 128 & 100 \\
\hline & $0,8 \%$ & $29,7 \%$ & $69,5 \%$ & 100 & 100 \\
\hline Total & 1 & 38 & 89 & & \\
\hline \multirow{2}{*}{ Supervision } & 0 & 103 & 25 & 128 & 100 \\
\hline & 0 & $80,5 \%$ & $19,5 \%$ & 100 & 100 \\
\hline Total & 0 & 103 & 25 & & \\
\hline \multirow{2}{*}{ Learning organisation } & 0 & 89 & 39 & 128 & 100 \\
\hline & 0 & $69,5 \%$ & $30,5 \%$ & 100 & 100 \\
\hline Total & 0 & 89 & 39 & & \\
\hline Support & 0 & 87 & 41 & 128 & 100 \\
\hline Management & 0 & $68 \%$ & $32 \%$ & 100 & 100 \\
\hline Total & 0 & 87 & 41 & & \\
\hline \multirow{2}{*}{ patient safety perception } & 8 & 110 & 10 & 128 & 100 \\
\hline & $63 \%$ & $85,9 \%$ & $7,8 \%$ & 100 & 100 \\
\hline Total & 8 & 110 & 10 & & \\
\hline \multirow{2}{*}{ Cooperation within unit } & 0 & 113 & 15 & 128 & 100 \\
\hline & 0 & $88,3 \%$ & $11,7 \%$ & 100 & 100 \\
\hline Total & 0 & 113 & 15 & & \\
\hline \multirow{2}{*}{ Staffing } & 3 & 115 & 10 & 128 & 100 \\
\hline & $2,3 \%$ & $89,8 \%$ & $7,8 \%$ & 100 & 100 \\
\hline Total & 3 & 115 & 10 & & \\
\hline \multirow{2}{*}{ Hands-off \& transition } & 45 & 78 & 5 & 128 & 100 \\
\hline & $35,2 \%$ & $60,9 \%$ & $3,9 \%$ & 100 & 100 \\
\hline Total & 45 & 78 & 5 & & \\
\hline \multirow{2}{*}{ Non punitive response } & 14 & 103 & 11 & 128 & 100 \\
\hline & $10,9 \%$ & $80,5 \%$ & $8,6 \%$ & 100 & 100 \\
\hline Total & 14 & 103 & 11 & & \\
\hline \multirow{2}{*}{ Feedback } & 2 & 83 & 43 & 128 & 100 \\
\hline & $1,6 \%$ & $64,8 \%$ & $33,6 \%$ & 100 & 100 \\
\hline Total & 2 & 83 & 43 & & \\
\hline \multirow{2}{*}{ Open Communication } & 6 & 113 & 9 & 128 & 100 \\
\hline & $4,7 \%$ & $88,3 \%$ & $7,0 \%$ & 100 & 100 \\
\hline Total & 6 & 113 & 9 & & \\
\hline \multirow{2}{*}{ Frekuen event report } & 0 & 96 & 32 & 128 & 100 \\
\hline & 0 & $75 \%$ & $25 \%$ & 100 & 100 \\
\hline Total & 0 & 96 & 9 & & \\
\hline
\end{tabular}

Based on table 2, it can be seen that patient safety culture in the Hospital is in moderate category. Most of respondents stated that supervision, organizational learning, management support, collaboration between units, staffing, Hands-off \& transition, Non punitive response, feedback, open communication, and the frequency of reporting incidents in the medium-cultured category, only cooperation within units at high culture category. 
Table 3. Demographic data and patient safety culture at Jambi Teaching Hospital

\begin{tabular}{|c|c|c|c|c|c|c|c|c|c|}
\hline \multirow{3}{*}{ Variabel } & \multicolumn{8}{|c|}{ Budaya Keselamatan Pasien } & \multirow{2}{*}{-value } \\
\hline & \multicolumn{3}{|c|}{ Rendah } & \multicolumn{2}{|l|}{ Sedang } & \multicolumn{2}{|c|}{ Tinggi } & \multirow[b]{2}{*}{ Total } & \\
\hline & $\mathrm{N}$ & $\%$ & $\mathrm{~N}$ & $\%$ & $\mathrm{~N}$ & $\%$ & & & \\
\hline \multicolumn{10}{|l|}{ Gender } \\
\hline Laki-laki & 0 & 0 & 6 & 100 & 0 & 0 & 6 & 4,68 & \multirow{2}{*}{0,679} \\
\hline Perempuan & 7 & 5,7 & 108 & 88,5 & 7 & 5,7 & 122 & 95,3 & \\
\hline \multicolumn{10}{|l|}{ Usia } \\
\hline $26-35$ years & 1 & 1,7 & 54 & 91,5 & 4 & 6,8 & 59 & 46,0 & 0,529 \\
\hline 36 - 45 years & 5 & 11,4 & 37 & 84,1 & 2 & 4,5 & 44 & 34,3 & \\
\hline $46-55$ years & 1 & 4,3 & 21 & 91,3 & 1 & 4,3 & 23 & 17,9 & \\
\hline $56-60$ years & 0 & 0 & 2 & 100 & 0 & 0 & 2 & 1,56 & \\
\hline \multicolumn{10}{|l|}{ Pendidikan } \\
\hline D3 in nurse & 4 & 5 & 72 & 90 & 4 & 5 & 80 & 62,5 & \multirow{4}{*}{0,099} \\
\hline D4 in Nurse & 1 & 14,3 & 5 & 71,4 & 1 & 14,3 & 7 & 5,46 & \\
\hline Bch in nurse & 1 & 2,6 & 36 & 92,3 & 2 & 5,1 & 39 & 30,46 & \\
\hline Master in nurse & 1 & 50 & 1 & 50 & 0 & 0 & 2 & 1,56 & \\
\hline \multicolumn{10}{|l|}{ Unit Kerja } \\
\hline Inpatient care & 6 & 5 & 108 & 89,3 & 7 & 5,8 & 121 & 94,5 & \multirow{2}{*}{0.480} \\
\hline Outpatient care & 1 & 14,3 & 6 & 85,7 & 0 & 0 & 7 & 5,46 & \\
\hline
\end{tabular}

\begin{tabular}{|c|c|c|c|c|c|c|c|c|c|}
\hline \multicolumn{10}{|c|}{ Status Pernikahan } \\
\hline Belum nikah & 0 & 0 & 7 & 100 & 0 & 0 & 7 & 5,4 & \multirow{2}{*}{0,635} \\
\hline Sudah nikah & 7 & 5,8 & 107 & 88,4 & 7 & 5,8 & 121 & 94,5 & \\
\hline \multicolumn{10}{|c|}{ Employment st } \\
\hline Civil servant & 7 & 9,2 & 67 & 88,2 & 2 & 2,6 & 76 & 59,3 & \multirow[t]{2}{*}{0,023} \\
\hline privat & 0 & 0 & 47 & 90,4 & 5 & 9,6 & 52 & 40,6 & \\
\hline \multicolumn{10}{|c|}{ length of working } \\
\hline $1-3$ years & 6 & 9,2 & 57 & 87,7 & 2 & 3,1 & 65 & \multirow{4}{*}{9,3} & \multirow{4}{*}{0,326} \\
\hline $3-5$ years & 0 & 0 & 7 & 87,5 & 1 & 12,5 & 8 & & \\
\hline $5-10$ years & 0 & 0 & 12 & 100 & 0 & 0 & 12 & & \\
\hline$>10$ years & 1 & 2,3 & 38 & 88,4 & 4 & 9,3 & 43 & & \\
\hline
\end{tabular}

Based on table 3 , it can be seen that $88.5 \%$ of 128 respondent were in moderate patient safety culture. $91.5 \%$ respondents aged $26-35$ years. $90 \%$ of all respondents with diploma in education were in a moderate patient safety culture. $89.3 \%$ who work in inpatient units have a moderate patient safety culture. $88.4 \%$ of all respondents with married status have a moderate patient safety culture. $88.2 \%$ of respondents have employment status as civil servants. Most of the respondents who have worked
1-3 years have a moderate patient safety culture as many as 57 respondents $(87.7 \%)$.

\section{DISSCUSION}

$88,5 \%$ of 122 female respondents were in moderate category. The results of statistical tests using chi-square test obtained p-value 0.679 which means there is no relationship between gender and patient safety culture. This research is in line with research conducted by Nivilinda (2013) which states that in nursing 
management there is no ideal limit for the ratio of male and female nurses, but in nursing management regarding service schedule arrangements, it is recommended that in one shift there are male and female nurses so that if taking privacy measures can be performed by nurses of the same sex.

$48,6 \%$ of all nurses aged in range $26-35$ years $91.5 \%$ of them were in moderate category the results of statistical tests using the chi-square test obtained p-value 0.529 which means there is no relationship between age and patient safety culture. This research is in line with research conducted by Sabila (2014) which shows that young adults (20-40 years) are the peak developmental age in applying knowledge and skills and the habit of rational thinking will increase.

$62,5 \%$ of all nurses graduated from diploma 3 in nursing. $90 \%$ of them was in moderate categorized. The level of nurse education will make nurses accustomed to being more rational and creative in accepting various renewal efforts and being able to adapt to these reforms. The majority of respondents who work in inpatient units have a moderate patient safety culture as many as 108 respondents $(89.3 \%)$ The results of statistical tests using the chi-square test obtained a p-value 0.480

$88.4 \%$ of 128 respondents have been married. The results of statistical tests using the chi-square test obtained p-value 0.635 which means there is no relationship between marital status and patient safety culture in Inpatient and Outpatient care unit. $76 \%$ of all respondent that involved in this study was civil servant. $88.2 \%$ of them was in moderate category. $87.7 \%$ of the respondents had worked 1-3 years in the hospital. Most of them in moderate category. The results of statistical tests using the chi-square test obtained p-value of 0.326 which means there was no relationship between length of work and patient safety culture in Inpatient and Outpatient care unit. The longer the nurse works, doesn't means the more cases are handled so that the experience increases, and vice versa, the shorter the nurse works, the fewer cases they handle.

\subsection{Dimensions of Patient Safety Culture in The Hospital}

\subsubsection{Cooperation within the unit}

In dimension of cooperation, $69.5 \%$ of all respondents in high category which means safety culture in the dimension of cooperation within the unit is categorized as high culture. Cooperation in units shows the extent to which members of a division are cohesive and work together in teams. Cooperation is defined as a collection of individuals with specific skills who work together and interact to achieve common goals. [2] While Thompson (2000) in (Setiowati, 2010) defines a team as a group of people who are interrelated with information, resources, skills, and trying to achieve common goals. The chance of the incident occurring as a result of certain conditions. Conditions that facilitate errors include environmental disturbances and teamwork that does not work. [3] According to Lestari (2013) communication barriers and an unbalanced division of tasks are the causes of ineffective teamwork. [4]

\subsubsection{Supervision}

In dimension of supervision, the role of the leader is very dominant in determining the failure and success of an organization. supervision has a moderate response of $80.5 \%$ which illustrates that the dimension of supervision can be interpreted as being cultured. Human resources in the hospital as individuals who directly implement health services must be able to meet needs both in quality and quantity. The quality element of a person can be seen from the element of education and the basic competencies they have. Competence of human resources in hospitals can be carried out through efforts to meet competency standards of each officer in accordance with the standards set by the profession. Hospitals can implement measures such as delegating officers to attend competency-based training.

\subsubsection{Organizational Learning}

Based on the results of research on the organizational learning dimension or continuous improvement regarding patient safety, it was measured from 3 statements. In this dimension, the response obtained is $69.5 \%$ which can be interpreted as a safety culture in the organizational learning dimension in the Outpatient and Inpatient Unit, which is categorized in moderate culture. Organizational learning or continuous improvement is carried out by a special team in strategizing patient safety culture values. Feedback from organizations and teammates is a form of organizational learning and is an effort to evaluate the effectiveness of programs that are already running [5]. 


\subsubsection{Management support}

In dimensions of management support for patient safety there are 4 statements that are measured in this dimension. In this dimension, the response obtained 68\%, which can be categorized that the patient safety culture in this dimension can be said to be moderate. In the dimensions of expectations and actions of managers to promote patient safety, what is meant by the manager here is the direct supervisor of each executive nurse, namely the head of the room. The head of the room is a nurse who has the duty and responsibility to regulate and control the activities of nurses in the ward to ensure safe care for patients [6]. Strong leadership, one of which must be possessed by the head of the room, can build a patient safety culture that allows the entire team to support and improve patient safety [7].

\subsubsection{Perceptions of patient safety}

Based on the results of this study, dimensions of perception of patient safety had a response of $85.9 \%$ which illustrates that the dimensions of perception of hospital staff about patient safety can be interpreted as being cultured. This shows that the level of understanding and knowledge of patient safety perceptions by respondents so far is sufficient, however it is better if the interpretation for health workers in the hospital should be in the high category. Perception is the process of interpreting sensations so that they make them meaningful. The process of observing someone that comes from cognitive abilities that is influenced by factors of the learning process, empirical experience, paradigm and one's knowledge. Many factors that influence perceptions can come from the parties who form perceptions [8].

\subsubsection{Cooperation between units}

Dimension of teamwork in the Outpatient and Inpatient Unit showed there was a positive response of $88.3 \%$ which could be interpreted as having a moderate culture. Cooperation between units indicates the extent of cohesiveness and teamwork between units or parts of providing health services to patients. This cooperation can be interpreted in terminology as a group of people with special skills who work together and interact to achieve the goals of the institution. [2]

\subsubsection{Staffing}

Based on the results of this study, staffing dimension had a response of $89.8 \%$ which illustrates that the staffing dimension can be interpreted as moderate culture. Human resources in the hospital as individuals who directly implement health services must be able to meet both in quality and quantity. The quality element of a person can be seen from the element of education and the basic competencies they have. Competence of human resources in hospitals can be carried out through efforts to meet the competency standards of each officer in accordance with the standards set by the profession. Hospitals can implement measures such as delegating officers to attend competency-based training

\subsubsection{Hands-off \& transitions}

Based on the results of this study, dimensions of handoffs and transitions between service units had a response of $60.9 \%$ which illustrates that dimensions of hands-off work and patient transition can be categorized in moderate culture. Hand-offs and transitions are related to cooperation within units and between units, the profession that usually undergoes shift changes is of course a nurse. According to Hamdani (2017), transition is a process of moving patients from one place to another. Transfer of patients from a unit to another can be in the form of moving patients from the emergency room to the unit in order to get treatment. In this transfer, an error can occur that endangers the patient such as the fall of the patient and misinformation when there is an exchange of information about the patient. Misinformation about these patients can also occur at change of shift between nurses. [9]

\subsubsection{Non-punitive response to errors}

Nurses and patients are treated fairly when an incident occurs. When an incident occurs, it should not focus on finding individual mistakes but rather study the system that results in errors. A culture of not blaming needs to be developed to strengthen a culture of patient safety. Based on the results of the study, the dimension of the no-blame response at the Jambi Teaching Regional Hospital had a response that was $80.5 \%$, which means moderate culture. Even so, there are nurses who worry that the mistakes they make will be recorded in personal documents by the leadership and worry that they will be blamed or punished. Penalties for a mistake are used to correct and prevent the same mistakes from recurring. 


\subsubsection{Feedback}

In the dimensions of feedback and communication to errors, $64.8 \%$ of the responses were categorized as moderate culture. Feedback and communication of errors or errors is very important after reporting of each incident to patient safety. One of the core principles in incident reporting according to Mahajan (2011) in Hamdani (2007) is that reporting can only provide benefits if it is responded to in a constructive manner. At least there is feedback from the analysis of findings. Ideally there are recommendations for changes to all systems. Feedback from organizations and teammates is a form of organizational learning. One of the barriers to recording and reporting systems is the lack of feedback on incident reports. [10]

\subsubsection{Open communication}

In open communication dimension there was a response of $88.3 \%$ which was categorized as a moderate patient safety culture. Since 2010 openness in communication has become a standard for the Joint Commission Accreditation of Health Organization (JCI) (2011). [1] Open communication can be applied at the time of operand or handover of patients, nursing rounds, and briefings before carrying out activities. At the time of handover, a nurse is expected to be able to communicate openly by communicating to other nurses about the risk factors for an incident. Briefing can be used as a way to obtain information related to current issues related to the culture of patient safety, nurses can also ask questions freely and openly about patient safety that are at risk of providing daily nursing care. Nursing rounds can be done weekly and only focuses on patient safety [9].

Safety culture is an output of individual and group values, behaviors, competencies, and patterns and habits that reflect the commitment and style and skill of organizational management and patient safety. Patient safety culture is an important thing because building a patient safety culture is a way of building a patient safety program as a whole, because if we focus on patient safety culture it will produce more safety results when compared to just focusing on the program. An organizational culture that prioritizes patient safety in providing health services will create a high patient safety culture in a hospital. Based on the description above, it can be seen that the level of patient safety culture was in the moderate culture category.

\section{CONCLUSIONS AND SUGGESTIONS}

The results of this study have shown that the study of the overall patient safety culture in the Outpatient and Inpatient care unit was categorized in a moderate culture of safety culture. The patient safety culture measurement questionnaire can be applied by nurses to obtain a situational picture and the level of quality of the application of patient safety culture related to the development of 12 scope or dimensions of patient safety culture from HSOPSC (Hospital Survey on Patient Safety Culture). Hospitals need to create a good patient safety culture to increase nurse job satisfaction which affects the performance of nurses. The leader of the hospital can increase structural empowerment in the hospital environment by rewarding employees' achievements and creating flexibility in the work given, focusing staff work on the goals the organization wants to achieve and making it easier for staff to achieve organizational goals.

\section{AUTHORS' CONTRIBUTIONS}

Muthia Mutmainnah, Kamariyah, Luri Mekeama, Nila Budi Setia, tuti ariyani and Muhammad Syir were responsible for study conception and design. Administrative activities were done by Muthia Mutmainnah. Nila Budi Setia were responsible for data collection. Kamariyah and Luri Mekeama were responsible for analysis data. Critical revisions for important intellectual content were done by Muthia Mutmainnah.

\section{ACKNOWLEDGMENTS}

Thanks to all nurses in Jambi Teaching Hospital as a place of research. Thank to Kamariyah, Luri Mekeama, Nila Budi Setia, Tuti Ariyani, and Muhammad Syir for their hard work in registering participants, data collection, and other administrative activities. This research was funded by Universitas Jambi.

\section{REFERENCES}

[1] Joint Commision International (JCI). Patient Safety, essentials for health care. (International Edition).USA. 2011 
[2] Ilyas. Kiat Sukses Manajemen Tim Kerja [Work Team Management Success Tips]. Jakarta: Gramedia Pustaka Utama. 2003.

[3] Thompson, L. A guide for managers. New Jersey: Pretice-Hall Inc. 2000

[4] Lestari dkk. Konsep Manajemen Keselamatan Pasien Berbasis Program Di RSUD Kapuas Provinsi Kalimantan Tengah. 2013 [Program-Based Patient Safety Management Concept at Kapuas Hospital, Central Kalimantan Province]. FKG. Universitas Padjajaran. Culture" in Dutch Hospital. BMC Health Services Research. 2008. 8(230):1-9. Patient Safety Culture. BMC Health Services Research. 2013. 10(199):1-13.

[5] Bodur S, Emel F. Validity and Reliability of Turkish version of "Hospital Survey on Patient Safety Culture" and Perception of Patient Safety in Public Hospitals in Turkey. BMC Health Services Research. 2017. 10(28):1-9.

[6] Gillies, D. A. 2006. Manajemen Keperawatan Suatu Pendekatan Sistem. Edisi Kedua [Nursing Management A Systems Approach. Second Edition]. Terjemahan Illiois W. B. Saunders Company.

[7] Nivalinda dkk. 2013. Pengaruh Motivasi Perawat Dan Gaya Kepemimpinan Kepala Ruang Terhadap Penerapan Budaya Keselamatan Pasien Oleh Perawat Pelaksana Pada Rumah Sakit Pemerintah di Semarang [The Influence of Nurse Motivation and Head of Room Leadership Style on the Implementation of Patient Safety Culture by Implementing Nurses at Government Hospitals in Semarang]. FK Universitas Diponegoro. Semarang.

[8] Robbins, S P. Perilaku Organisasi [Organizational behavior]. 2006. New Jersey.Practice Hall.

[9] Hamdani, Siva. Analisis Budaya Keselamatan Pasien Di Rumah Sakit Islam Jakarta Tahun 2017 [Analysis of Patient safety Culture in Jakarta Islamic Hospital 2017]. Tesis. FKM UI.

[10] Mahajan RP. Clinical incident reporting and learning. British of Journal Anaesthesia., 2011. 105:69-75.

[11] Reason, J. (2000). Human error: Models and management. Journal BMJ, 320

[12] Nurmalia, Devi. Pengaruh Program Mentoring Keperawatan terhadap Penerapan Budaya
Keselamatan Pasien di Ruang Rawat Inap RS Sultan Agung Semarang . [The Effect of the Nursing Mentoring Program on the Implementation of Patient Safety Culture in the Inpatient Room of Sultan Agung Hospital Semarang]. Tesis. 2014. FKM UI.

[13] Gagliardi, A. R., Perrier, L., Webster., F., Leslie., K., Bell., M., Levinson., W., . Straus., S. E. (2016). Exploring mentorship as a strategy to build capacity for knowledge translation research and practice: protocol for a qualitative study. BioMed Central $4(55)$. 